\title{
HARUSKAH E-PAYMENT TRUST DITERAPKAN E-COMMERCE SEBAGAI FAKTOR KEPUASAN KONSUMEN?
}

\author{
Arbi Siti Rabiah ${ }^{1}$ \\ Mochammad Fahlevi \\ Nendi Juhandi ${ }^{3}$ \\ Pawit Winarto ${ }^{3}$
'Management Department, BINUS Business School, Bina Nusantara University, Jakarta, Indonesia 11480
Management Department, BINUS Online Learning, Bina Nusantara University, Jakarta, Indonesia 11480
${ }^{3}$ Management Department, STIE Kusuma Negara, Jakarta, Indonesia 13770
email : mochammad.fahlevi@binus.ac.id \\ ${ }^{2}$
}

\begin{abstract}
ABSTRAK
Kepercayaan konsumen terkait dengan pembayaran menjadi topik penting pada beberapa penelitian mengenai pembelanjaan online. Konsumen sangat memperhatikan keamanan dalam bertransaksi termasuk ketika melakukan pembayaran secara non-tunai. Penelitian ini menggunakan uji non-parametrik menggunakan SmartPLS dengan 243 responden yang dijadikan sampel. Hasil Penelitian ini memberikan informasi bahwa E-payment trust merupakan salah satu faktor penting untuk kepuasan konsumen pada E-commerce di Indonesia. Kepercayaan terkait dengan pembayaran sangat berhubungan dengan keamanan informasi dan keamanan data privasi konsumen ketika melakukan transaksi pada E-commerce.

Kata kunci: Trust; E-Payment; Customer Satisfaction; E-Commerce.
\end{abstract}

\begin{abstract}
Consumer trust related to payment is an important topic in several studies of online shopping. Consumers are very concerned about security in transactions including when making payments in cashless. This study uses a non-parametric test using SmartPLS with 243 respondents used as samples. The results of this study provide information that E-payment trust is an important factor for consumer satisfaction in E-commerce in Indonesia. Trust related to payments is closely related to information security and data privacy security of consumers when making transactions on E-commerce.

Keywords: Trust; E-Payment; Kepuasan Konsumen; E-Commerce.
\end{abstract}




\section{PENDAHULUAN}

E-commerce adalah sebuah tempat bertamunya penjual dan pembeli atau produsen dan konsumen yang ingin melakukan transaksi secara online melalui jaringan internet (Suwarni et al., 2020). Perkembangan internet dan digital sangat pesat di era globalisasi menyebabkan terbentuknya dunia bisnis yang baru, dimana setiap orang memiliki kemampuan untuk berkomunikasi dengan orang lainnya tanpa ada batasan (Sutia et al., 2020). Pada saat ini konsumen dapat dengan mudahnya melakukan transaksi jual beli secara online. Era globalisasi menuntut layanan dan jasa yang serba cepat dan mudah. Di era ini mulai bermunculan E-commerce yang berguna sebagai penghubung antara konsumen dan produsen, dimana pada E-commerce penjual dan pembeli dapat melakukan transaksi jual beli melalui layanan internet dan melakukan pembayaran secara online melalui mobile banking (Suwarni et al., 2020). Layanan perbankan saat ini sudah banyak mengalami perubahan dengan kemajuan teknologi. Perbankan di Indonesia berusaha mengimbangi fintech yang bermunculan cukup maju di Indonesia sehingga semakin lama mengambil peran perbankan (Kasbuntoro et al., 2020).

Perbankan mengembangkan layanan pembayaran yang fleksibel dan dapat dilakukan kapan saja seperti menggunakan E-banking atau mobile banking, nasabah dapat memanfaatkan layanan perbankan tanpa batas waktu tertentu selama 24 jam penuh dan dapat melakukan pembayaran yang sifatnya non-tunai, bahkan saat ini perbankan sudah bekerjasama dengan beberapa $E$ commerce untuk menyediakan pembayaran secara online dengan keamanan berlapis terutama dalam transaksi internasional lintas mata uang (Fahlevi et al., 2019). Layanan perbankan turut membantu E-commerce dalam melakukan transaksi sehingga kenyamanan dalam layanan pembayaran pada transaksi online menjadi hal penting bagi E-commerce untuk meningkatkan kerjasama dengan perbankan demi menghadirkan kenyamanan konsumen dalam melakukan pembayaran dengan banyak opsi pilihan pembayaran online.

Perkembangan dan penggunaan teknologi saat ini tumbuh dengan cepat dimulai dari komputer yang semakin canggih dan smartphone yang digunakan terus mengalami perubahan dan perbaikan dalam hal teknologi (Sutia et al., 2019). Pada awal hadirnya komputer dan internet hanya digunakan dalam hal pemasaran produk dan jasa perusahaan akan tetapi pada saat ini telah banyak berubah terutama dalam hal perdagangan seperti E-trade dan pembayaran yang dilakukan secara non-tunai dengan beberapa perangkat canggih seperti $E$ banking dan mobile banking (Putri \& Baridwan, 2014).

E-commerce memainkan peran penting bagi perusahaan untuk tetap kompetitif di pasar global. Perusahaan secara progresif mengadopsi sistem ecommerce, di mana mereka dipandang sebagai prosedur tahap, di mana perusahaan awalnya melebihi alasan untuk adopsi e-commerce. Ada beberapa keuntungan e-commerce dibandingkan dengan perdagangan tradisional, yang relatif berlaku untuk semua perusahaan. Misalnya, e-commerce mengarah pada disintermediasi rantai pasokan, yang berarti bahwa perusahaan dapat 
menghilangkan agen penjualan yang mahal dan mengurangi biaya. Selain itu, e-commerce memberikan akses ke pasar yang jauh karena dikatakan mengaburkan batas internasional (Suwarni et al., 2020).

Awalnya, konstitusi Indonesia tidak secara tegas menyatakan pembagian ekonomi adalah pedoman moneter yang dipersepsikan, namun pengaturan dalam konstitusi mengandung tingkat pengakuan tertentu atas pembagian keuangan. Konstitusi Indonesia menetapkan bahwa ekonomi akan disusun sebagai suatu usaha yang khas tergantung pada standar kerangka kerja keluarga. Lebih lanjut menetapkan bahwa asosiasi ekonomi nasional akan dipimpin berdasarkan pada aturan moneter mayoritas pemerintah mempertahankan standar persekutuan, efektivitas diri, dan menjaga keseimbangan dalam kemajuan dan solidaritas ekonomi nasional. Aturan ekonomi ini sangat mirip dengan ekonomi berbagi. Itu ditulis dalam karya penelitian mengenai ekonomi berbagi dicirikan sebagai kegiatan keuangan yang terkait secara digital termasuk kategori potensial yang menyertainya (misalnya. Dalam penyimpangan adalah yang dibuat oleh Cristiano Codagnone dan Bertin Martens sebagai pencipta Laporan Teknis JRC "Memeriksa Ekonomi Berbagi: Asal, Definisi, Dampak, dan Masalah Peraturan): distribusi barang dagangan (misalnya Craiglist, eBay); perluasan penggunaan sumber daya yang solid (misalnya Grab, Uber, dan Airbnb) (Suwarni et al., 2020).

Tampaknya keputusan yang masuk akal bagi banyak perusahaan untuk mengeksplorasi peluang e-commerce karena globalisasi di sektor bisnis dan semakin pentingnya melakukan bisnis internasional. Ketersediaan perangkat lunak e-commerce dan lembaga-lembaga pendukung merupakan faktor besar untuk adopsi e-commerce. Setelah perusahaan memilih untuk terlibat dalam ecommerce, proses implementasi dimulai. Selama proses ini, penting bagi perusahaan untuk membedakan enabler dan penghambat implementasi ecommerce. E-commerce adalah alat yang melaluinya perusahaan dapat mencapai keunggulan kompetitif. Oleh karena itu, menarik untuk mengeksplorasi lebih lanjut bagaimana perusahaan benar-benar menerapkan sistem e-commerce dan jalur mana perusahaan mengambil dari menghasilkan ide e-commerce hingga realisasi keberhasilan e-commerce. Juga, perusahaan besar terikat untuk mengadopsi teknologi baru daripada perusahaan kecil karena skala ekonomi. Konteks lain yang menarik untuk dipelajari adalah konteks industri, karena menerapkan e-commerce memerlukan kompetensi yang berbeda di berbagai sektor ekonomi (Fahlevi et al., 2019).

Istilah Unicorn, memiliki arti berbeda dalam hal pendanaan dalam dunia bisnis. Unicorn terkait dengan perusahaan bisnis startup teknologi mana pun yang dapat mencapai nilai pasar \$ 1 miliar sebagaimana disimpulkan oleh pengeluaran pribadi atau publik. Istilah ini awalnya disebutkan oleh Aileen Lee, pendiri Cowboy Ventures. Unicorn dianggap sebagai fenomena yang terjadi dalam Sumber Daya Manusia, ketika orang yang mengawasi rekrutmen kandidat memiliki harapan yang tidak mungkin bagi mereka yang mereka rekrut. Ini membentuk perbedaan antara harapan majikan dan tenaga kerja yang tersedia di pasar. Pada dasarnya, Sumber Daya Manusia mencari kandidat mitos (unicorn) daripada yang tersedia di pasar. 
Pada dasarnya, Startup adalah implementasi dari rencana bisnis di mana segala sesuatu yang telah direncanakan dan diproyeksikan dalam rencana bisnis dicurahkan dan direalisasikan dalam bentuk startup. Tidak disebutkan tentang apa ukuran perusahaan atau sektor industri. Valuasi startup adalah nilai ekonomi bisnis yang melibatkan perusahaan startup. Penilaian biasanya digunakan sebagai referensi untuk mengukur seberapa besar potensi bisnis suatu perusahaan. Mengutip Tech in Asia, perhitungan startup dan penilaian perusahaan konvensional tidak jauh berbeda. Penilaian perusahaan konvensional mempertimbangkan beberapa aspek termasuk nilai perusahaan pada saham pertukaran, nilai jenis saham lain yang dimiliki perusahaan, utang perusahaan, dan perusahaan yang dimiliki uang tunai.

Sedangkan untuk startup yang sudah sejak tahap awal kedudukan bisnis belum mendapatkan penghasilan atau untung. Pendiri perusahaan atau calon investor akan mempertimbangkan aspek-aspek seperti jumlah transaksi dan nominal, jumlah pengguna, teknologi produk, kualitas tim, dan pesaing. Perusahaan yang mengantongi status unicorn berdasarkan penilaian yang dikembangkan oleh pemodal ventura dan investor yang berpartisipasi dalam putaran pendanaan. Semua unicorn sebenarnya adalah startup, hanya nilainya dinilai berdasarkan potensi pertumbuhan dan pengembangan bisnis.

Berdasarkan latar belakang yang telah dituliskan, maka yang menjadi masalah utama dalam penelitian ini ialah apakah kepercayaan pada E-payment berpengaruh terhadap kepuasan konsumen pengguna E-commerce Tokopedia. Tujuan dari penelitian ini ialah mengetahui pengaruh kepercayaan pada $E$ payment terhadap kepuasan konsumen pengguna E-commerce Tokopedia. Penelitian ini dapat memberikan informasi dampak dari perkembangan dan evaluasi penggunaan E-payment terhadap konsumen pengguna $E$-commerce Tokopedia. Penelitian ini dapat mencari tahu apakah pada E-payment memiliki inovasi terbaik dalam memperoleh keuntungan khususnya terhadap pengguna E-commerce Tokopedia.

E-payment system didefinisikan sebagai pertukaran nilai antar pihak dalam transaksi bisnis melalui jaringan teknologi informasi dan komunikasi (Ayo \& Ukpere, 2010). Sistem pembayaran ini muncul dalam dunia bisnis karena semakin banyak toko online dan transaksi online yang dilakukan oleh masyarakat. Kehadiran E-commerce membuat sistem pembayaran semakin berkembang menyediakan banyak opsi pembayaran kepada konsumen sebagai bentuk layanan. E-commerce pada dasarnya mengandalkan pembayaran yang sifatnya non-tunai, sehingga perlu bagi E-commerce mengembangkan $E$ payment system (Ayo \& Ukpere, 2010).

Sistem pembayaran online memiliki banyak kelebihan dibandingkan sistem pembayaran tradisional yakni transaksi tidak terikat oleh ruang dan waktu sehingga dapat dilakukan kapanpun dan dimanapun dalam melakukan pembayaran sehingga akan lebih praktis untuk konsumen melakukan pembayaran secara online ketika membeli sesuatu (Putri \& Baridwan, 2014). E-payment selain mempermudah manusia dalam melakukan transaksi juga turut mengurangi pemanasan global karena tidak membutuhkan kertas dan hal yang dibutuhkan dalam transaksi secara tradisional. 
Teori besar dalam penerimaan informasi diambil dari Trust Theory. Kepuasan konsumen sangat bergantung pada kepercayaan sebagaimana ketika melakukan pembelian sesuai dengan yang diharapkan oleh konsumen (Yousafzai et al., 2003). Sistem pembayaran online harus memperhatikan faktor keamanan karena sangat berbeda dengan sistem pembayaran tradisional (Linck et al., 2007). Sistem keamanan dan perlindungan dalam E-payment system menjadi hal utama yang dijadikan pertimbangan konsumen untuk melakukan transaksi, ketika kedua hal ini sudah terpenuhi maka konsumen tidak akan ragu dalam melakukan pembayaran. Segala bentuk risiko harus dihindari karena akan berdampak pada kurangnya kepercayaan konsumen kepada perusahaan.

Pembayaran secara online lebih dikenal dengan E-payment yaitu pembayaran yang dilakukan dalam transaksi dengan transfer sejumlah nilai uang secara real-time (Kim et al., 2010). Perusahaan harus melakukan kerjasama dengan perbankan atau perusahaan keuangan yang menyediakan layaanan pembayaran secara online atau E-payment.

Menurut Kotler dan Keller (2009) kepuasan konsumen merupakan perbandingan antara hasil yang telah dinikmati oleh konsumen dengan harapannya. Konsumen akan selalu berharap bahwa barang atau jasa yang dibeli sesuai dengan harapannya sehingga akan menimbulkan persaaan senang karena telah sesuai dengan harapannya. Kepercayaan telah diidentifikasi menjadi faktor pendorong utama loyalitas pelanggan (Horppu et al., 2008).

Dalam konteks penelitian ini, kepuasan mengacu pada respons evaluatif pasca-pilihan dan afektif dari pengguna untuk pengalaman mereka dengan mobile payment; selain itu, kepuasan ditangkap sebagai perasaan positif (kepuasan), ketidakpedulian, atau perasaan negatif (ketidakpuasan) (Cao et al., 2018). Dwyer et al. (1987) menganggap kepuasan sebagai evaluasi global terhadap hubungan yang dapat dipercaya. Selain itu, sesuai dengan teori diperpanjang dari tindakan beralasan yang diusulkan oleh (Lin \& Wang, 2006), kita tahu bahwa kepercayaan dapat memengaruhi sikap. Dari sorotan ini, kami berpendapat bahwa kepercayaan pengguna yang dipercaya dapat memengaruhi sikap mereka, yaitu kepuasan. Dalam layanan E-payment, kepercayaan kepercayaan merujuk pada persepsi pengguna tentang atribut penyedia layanan, termasuk kemampuan, integritas, dan kebajikan penyedia. (Mc Knight et al., 2002). Ketika pengguna menganggap penyedia layanan pembayaran elektronik dapat diandalkan dan secara umum dapat dipercaya, mereka akan puas dengan pembayaran elektronik dan secara positif mengevaluasi layanan tersebut. Jika pengguna tidak percaya pada pembayaran elektronik, mereka mungkin tidak puas dengan layanan dan menghasilkan evaluasi negatif. Hubungan antara kepercayaan dan kepuasan juga didukung oleh penelitian sebelumnya (Elbeltagi \& Agag, 2016; Gwebu et al., 2014; Zhu \& Chen, 2012). 


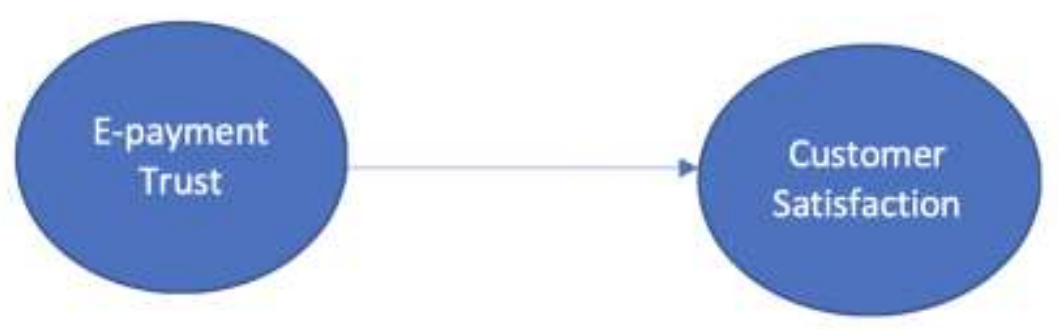

Sumber: Peneliti (2020)

\section{Gambar 1. Kerangka Konsep}

Ho: Tidak terdapat pengaruh yang signifikan antara E-payment trust terhadap kepuasan konsumen pada E-commerce

Ha: Terdapat pengaruh yang signifikan antara E-payment trust terhadap kepuasan konsumen pada E-commerce

\section{METODE PENELITIAN}

Jenis penelitian ini adalah explanative research dengan menggunakan pendekatan kuantitatif. Penelitian Eksplanatori dilakukan untuk masalah yang belum diteliti dengan baik sebelumnya, menuntut prioritas, menghasilkan definisi operasional dan menyediakan model yang diteliti lebih baik. Ini sebenarnya adalah jenis desain penelitian yang berfokus pada menjelaskan aspek studi.

Peneliti mulai dengan ide umum dan menggunakan penelitian sebagai alat yang dapat mengarah ke mata pelajaran yang akan ditangani di masa mendatang. Ini dimaksudkan untuk memberikan perincian di mana sejumlah kecil informasi tersedia untuk produk tertentu dalam pikiran peneliti tersebut. Untuk memulai penelitian Anda, Anda perlu membuat garis besar penelitian atau garis besar pidato untuk melontarkan ide penelitian Anda saat menulis proposal penelitian kepada profesor atau bos Anda atau dalam rapat dewan.

Penelitian Eksplanatori dilakukan untuk membantu peneliti menemukan masalah yang tidak dipelajari sebelumnya secara mendalam. Penelitian penjelasan tidak digunakan untuk memberi peneliti beberapa bukti konklusif tetapi membantu kita dalam memahami masalah dengan lebih efisien. Saat melakukan penelitian, peneliti harus dapat menyesuaikan diri dengan data baru dan wawasan baru

Hal Ini tidak bertujuan untuk memberikan jawaban final dan konklusif untuk pertanyaan penelitian tetapi memungkinkan peneliti untuk mengeksplorasi penelitian dengan tingkat kedalaman yang berbeda-beda. "Juga telah diperhatikan bahwa" penelitian eksplorasi adalah pemeriksaan, yang membentuk dasar untuk berbagai pertanyaan tentang, itu adalah penghalang bangunan untuk melihat alternatif ke dalam, hal tersebut adalah blok bangunan untuk peneliti lain. Riset ini bahkan dapat membantu dalam menentukan konfigurasi eksplorasi, filosofi pengujian dan strategi pengumpulan informasi. Penelitian ini memungkinkan peneliti untuk mengatasi masalah seperti itu di 
mana tidak ada atau kurang penelitian yang telah dilakukan.

Menurut (Saunders et al., 2009), penelitian menurut tingkat penjelasan adalah penelitian yang bermaksud menjelaskan kedudukan variabel-variabel yang diteliti serta hubungan antara satu variabel dengan variabel yang lain. Populasi merupakan jumlah keseluruhan dari sebuah objek yang ingin diteliti dan terdiri atas individu-individu yang memiliki karakter yang berbeda dan dinilai mengandung informasi yang dibutuhkan (Hayes, 2013). Objek tersebut disebut sebagai unit analisis, yang dapat berupa orang-orang, institusi-institusi atau benda-benda. Populasi pada penelitian ini merupakan masyarakat Jakarta Barat yang berumur diatas 18 tahun dan mengetahui dan pernah berbelanja di Tokopedia dan menggunakan E-payment sebagai alat transaksi pembayaran pada Tokopedia. Sampel dalam penelitian ini menggunakan rumus Slovin dalam menentukan jumlah sampel dan didapati hasil sebanyak 243 responden yang dijadikan sampel dalam penelitian ini. Penelitian ini menggunakan metode analisis data dengan menggunakan software SmartPLS, Persamaan model struktural (SEM) berbasis varian yang secara simultan dapat melakukan pengujian model pengukuran sekaligus pengujian model struktural. Model pengukuran digunakan untuk uji validitas dan reabilitas, sedangkan model struktural digunakan untuk uji kausalitas (pengujian hipotesis dengan model prediksi) (J. F. Hair et al., 2017).

Pengukuran uji kelayakan dalam penelitian ini menggunakan nilai R2 yang terdapat pada output PLS. R2 adalah statistik yang akan memberikan beberapa informasi tentang goodness of fit model. Dalam regresi, koefisien determinasi R2 adalah ukuran statistik seberapa baik prediksi regresi mendekati titik data nyata. R2 dari 1 menunjukkan bahwa prediksi regresi sangat cocok dengan data.

Nilai R2 di luar rentang 0 hingga 1 dapat terjadi ketika model cocok dengan data yang lebih buruk daripada hyperplane horisontal. Ini akan terjadi ketika model yang salah dipilih, atau kendala tidak masuk akal diterapkan oleh kesalahan. Jika persamaan 1 dari Kvålseth digunakan (ini adalah persamaan yang paling sering digunakan), R2 bisa kurang dari nol. Jika persamaan 2 dari Kvålseth digunakan, R2 bisa lebih besar dari satu.

Dalam semua kasus di mana R2 digunakan, prediktor dihitung dengan regresi kuadrat-terkecil biasa: yaitu, dengan meminimalkan SSres. Dalam hal ini R2 meningkat ketika kita meningkatkan jumlah variabel dalam model (R2 adalah monoton meningkat dengan jumlah variabel termasuk — yaitu, tidak akan pernah berkurang). Ini menggambarkan kelemahan untuk satu kemungkinan penggunaan $\mathrm{R} 2$, di mana orang mungkin terus menambahkan variabel (regresi wastafel dapur) untuk meningkatkan nilai R2. Sebagai contoh, jika seseorang mencoba untuk memprediksi penjualan model mobil dari jarak tempuh gas mobil, harga, dan tenaga mesin, seseorang dapat memasukkan faktor-faktor yang tidak relevan seperti huruf pertama dari nama model atau ketinggian perancang insinyur utama. mobil karena R2 tidak akan pernah berkurang karena variabel ditambahkan dan mungkin akan mengalami peningkatan karena kebetulan saja.

Ini mengarah pada pendekatan alternatif dalam melihat R2 yang 
disesuaikan. Penjelasan statistik ini hampir sama dengan R2 tetapi ini menghukum statistik karena variabel tambahan termasuk dalam model. Untuk kasus-kasus selain pas dengan kuadrat terkecil biasa, statistik R2 dapat dihitung seperti di atas dan mungkin masih merupakan ukuran yang berguna. Jika pemasangan adalah dengan kuadrat terkecil tertimbang atau kuadrat terkecil umum, versi alternatif R2 dapat dihitung sesuai dengan kerangka kerja statistik tersebut, sedangkan R2 "mentah" mungkin masih berguna jika lebih mudah ditafsirkan. Nilai untuk R2 dapat dihitung untuk semua jenis model prediksi, yang tidak perlu memiliki basis statistik.

SmartPLS adalah perangkat lunak dengan antarmuka pengguna grafis untuk pemodelan persamaan struktural (SEM) berbasis varians menggunakan metode pemodelan jalur parsial paling sedikit (PLS). Selain memperkirakan model jalur dengan variabel laten menggunakan algoritma PLS-SEM, perangkat lunak menghitung kriteria penilaian hasil standar (misalnya, untuk model pengukuran reflektif dan formatif, model struktural, dan goodness of fit) dan mendukung analisis statistik tambahan (misalnya, analisis tentang konfirmasi, analisis peta kinerja-penting, segmentasi, multigroup), karena SmartPLS diprogram di Jawa, ini dapat dijalankan dan dijalankan pada sistem operasi komputer yang berbeda (J. Hair et al., 2010).

Analisis partial least square (PLS) adalah alternatif untuk regresi OLS, korelasi kanonik, atau pemodelan persamaan struktural berbasis kovarian (SEM) sistem variabel independen dan respon. Bahkan, PLS kadang-kadang disebut "SEM berbasis komposit", "SEM berbasis komponen", atau "SEM berbasis varians", berbeda dengan "SEM berbasis kovarians," yang merupakan jenis yang biasa (misalnya, diterapkan oleh Amos, SAS, Stata, MPlus, LISREL, EQS dan paket perangkat lunak utama lainnya). Di sisi respons, PLS dapat menghubungkan himpunan variabel independen ke variabel dependen (respons) ganda. Di sisi prediktor, PLS dapat menangani banyak variabel independen, bahkan ketika prediktor menampilkan multikolinieritas. PLS dapat diimplementasikan sebagai model regresi, memprediksi satu atau lebih tanggungan dari satu set satu atau lebih independen; atau dapat diimplementasikan sebagai model jalur, menangani jalur kausal yang menghubungkan prediktor serta jalur yang menghubungkan prediktor dengan variabel respons. PLS diimplementasikan sebagai model regresi oleh SPSS dan oleh SAS PROC PLS. SmartPLS adalah implementasi yang paling umum sebagai model jalur (J. F. Hair et al., 2017).

PLS dicirikan sebagai teknik yang paling cocok jika tujuan penelitiannya adalah prediksi atau pemodelan eksplorasi. Secara umum, SEM berbasis kovarian lebih disukai ketika tujuan penelitian adalah pemodelan konfirmatori. PLS kurang memuaskan sebagai teknik penjelasan karena rendah daya untuk menyaring variabel kepentingan kausal minor (J. F. Hair et al., 2017).

\section{HASIL DAN PEMBAHASAN}

Statistik deskriptif adalah statistik ringkasan yang secara kuantitatif menggambarkan atau merangkum fitur dari kumpulan informasi, sedangkan statistik deskriptif (dalam arti kata benda massa) adalah proses menggunakan 
dan menganalisis statistik tersebut. Statistik deskriptif dibedakan dari statistik inferensial (atau statistik induktif) dengan tujuannya untuk merangkum sampel, daripada menggunakan data untuk mempelajari tentang populasi yang dianggap mewakili sampel data. Ini umumnya berarti bahwa statistik deskriptif, tidak seperti statistik inferensial, tidak dikembangkan berdasarkan teori probabilitas, dan sering statistik non-parametrik. Bahkan ketika analisis data menarik kesimpulan utamanya menggunakan statistik inferensial, statistik deskriptif umumnya juga disajikan. Misalnya, dalam makalah yang melaporkan subyek manusia, biasanya sebuah tabel disertakan untuk memberikan ukuran sampel keseluruhan, ukuran sampel dalam subkelompok penting (misalnya, untuk setiap kelompok perlakuan atau paparan), dan karakteristik demografi atau klinis seperti usia rata-rata, proporsi subyek dari setiap jenis kelamin, proporsi subyek dengan variabel terkait.

Beberapa ukuran yang biasa digunakan untuk menggambarkan kumpulan data adalah ukuran kecenderungan sentral dan ukuran variabilitas atau dispersi. Ukuran tendensi sentral meliputi mean, median, dan mode, sedangkan ukuran variabilitas meliputi deviasi standar (atau varians), nilai minimum dan maksimum dari variabel, kurtosis dan skewness.

Statistik deskriptif memberikan ringkasan sederhana tentang sampel dan tentang pengamatan yang telah dilakukan. Ringkasan tersebut dapat berupa statistik ringkasan, yaitu statistik ringkasan, atau visual, mis. Grafik yang mudah dipahami. Ringkasan ini dapat membentuk dasar dari deskripsi awal data sebagai bagian dari analisis statistik yang lebih luas, atau mereka mungkin cukup dalam dan dari diri mereka sendiri untuk penyelidikan tertentu.

Misalnya, persentase pemotretan dalam bola basket adalah statistik deskriptif yang merangkum kinerja pemain atau tim. Jumlah ini adalah jumlah tembakan yang dibuat dibagi dengan jumlah tembakan yang diambil. Misalnya, pemain yang menembak 33\% menghasilkan sekitar satu tembakan di setiap tiga. Persentase merangkum atau menjelaskan beberapa peristiwa terpisah. Pertimbangkan juga nilai rata-rata poin. Angka tunggal ini menggambarkan kinerja umum seorang siswa di seluruh jajaran pengalaman kursus mereka.

Penggunaan statistik deskriptif dan ringkasan memiliki sejarah yang luas dan, memang, tabulasi sederhana populasi dan data ekonomi adalah cara pertama topik statistik muncul. Baru-baru ini, kumpulan teknik ringkasan telah dirumuskan di bawah judul analisis data eksplorasi: contoh teknik semacam itu adalah plot kotak.

Dalam dunia bisnis, statistik deskriptif menyediakan ringkasan yang berguna dari banyak jenis data. Misalnya, investor dan broker dapat menggunakan akun historis perilaku pengembalian dengan melakukan analisis empiris dan analitik atas investasi mereka untuk membuat keputusan investasi yang lebih baik di masa depan.Survei dilakukan dan disebarkan secara elektronik menggunakan google form dan microsoft form. Berikut tabel di bawah ini menjelaskan deskripsi identitas diri dari para responden. 
Tabel 1.

Deskripsi Identitas Responden

\begin{tabular}{ll}
\hline Kategori & Presentase \\
\hline Usia Responden & \\
$<20$ Tahun & $58,1 \%$ \\
$>20$ Tahun & $41,9 \%$ \\
Pekerjaan & \\
Pelajar & $74,2 \%$ \\
Karyawan & $17 \%$ \\
Wiraswasta & $5,8 \%$ \\
Lainnya & $2 \%$ \\
Pendapat Kepuasan & \\
Sangat Puas & $61,3 \%$ \\
Tidak Puas & $38,7 \%$ \\
\hline
\end{tabular}

Sumber: Peneliti (2020)

Kami memberikan kuisioner yang disebar kepada beberapa responden sebanyak 243 responden dengan mayoritas responden yaitu $58,1 \%$ berumur dibawah 20 tahun. 74,2\% pekerjaan dari para responden adalah sebagai pelajar dan sisanya ialah sebagai karyawan, wirausaha, dan lainnya. 54,6\% dari para responden berpendapat bahwa penggunaan E-payment sangat membantu saat berbelanja online dan $61,3 \%$ dari para responden merasa puas terhadap interface E-payment.

Dalam statistik, koefisien determinasi, dilambangkan R2 atau r2 dan diucapkan "R kuadrat", adalah proporsi varians dalam variabel dependen yang dapat diprediksi dari variabel independen. Ini adalah statistik yang digunakan dalam konteks model statistik yang tujuan utamanya adalah prediksi hasil di masa depan atau pengujian hipotesis, berdasarkan informasi terkait lainnya. Ini memberikan ukuran seberapa baik hasil yang diamati direplikasi oleh model, berdasarkan proporsi variasi total hasil yang dijelaskan oleh model.

Ada beberapa definisi R2 yang hanya terkadang setara. Satu kelas dari kasus-kasus tersebut termasuk regresi linier sederhana di mana 2 digunakan sebagai pengganti R2. Ketika intersep dimasukkan, maka r2 hanyalah kuadrat dari koefisien korelasi sampel (mis., R) antara hasil yang diamati dan nilai prediktor yang diamati. Jika regressor tambahan dimasukkan, R2 adalah kuadrat dari koefisien korelasi berganda. Dalam kedua kasus tersebut, koefisien determinasi biasanya berkisar dari 0 hingga 1 .

Ada kasus di mana definisi komputasi R2 dapat menghasilkan nilai negatif, tergantung pada definisi yang digunakan. Ini bisa muncul ketika prediksi yang dibandingkan dengan hasil yang sesuai belum diturunkan dari prosedur pemasangan model menggunakan data tersebut. Bahkan jika prosedur model-pas telah digunakan, R2 mungkin masih negatif, misalnya ketika regresi 
linier dilakukan tanpa termasuk intersep atau ketika fungsi non-linear digunakan untuk mencocokkan data. Dalam kasus-kasus di mana nilai-nilai negatif muncul, rata-rata data memberikan kecocokan yang lebih baik untuk hasil daripada nilai-nilai fungsi yang sesuai, menurut kriteria khusus ini. Karena definisi paling umum dari koefisien determinasi juga dikenal sebagai koefisien efisiensi model Nash-Sutcliffe, notasi terakhir ini lebih disukai di banyak bidang, karena menunjukkan indikator good-of-fit yang dapat bervariasi dari $-\infty$ hingga 1 (yaitu, dapat menghasilkan nilai negatif) dengan huruf kuadrat membingungkan.

PLS-SEM tidak menganggap bahwa data terdistribusi normal, yang menyiratkan bahwa uji signifikansi parametrik (mis., Seperti yang digunakan dalam analisis regresi) tidak dapat diterapkan untuk menguji apakah koefisien seperti bobot luar, beban luar, dan koefisien jalur signifikan. Sebaliknya, PLSSEM mengandalkan prosedur bootstrap nonparametrik untuk menguji signifikansi estimasi koefisien jalur di PLS-SEM.

Dalam bootstrap, subsampel dibuat dengan pengamatan yang diambil secara acak dari set data asli (dengan penggantian). Subsampel ini kemudian digunakan untuk memperkirakan model jalur PLS. Proses ini diulang sampai sejumlah besar sampel acak telah dibuat. Estimasi parameter (mis., Bobot luar, beban luar, dan koefisien jalur) yang diperkirakan dari sub-sampel digunakan untuk mendapatkan kesalahan standar untuk estimasi. Dengan informasi ini, nilai-t dihitung untuk menilai signifikansi setiap estimasi

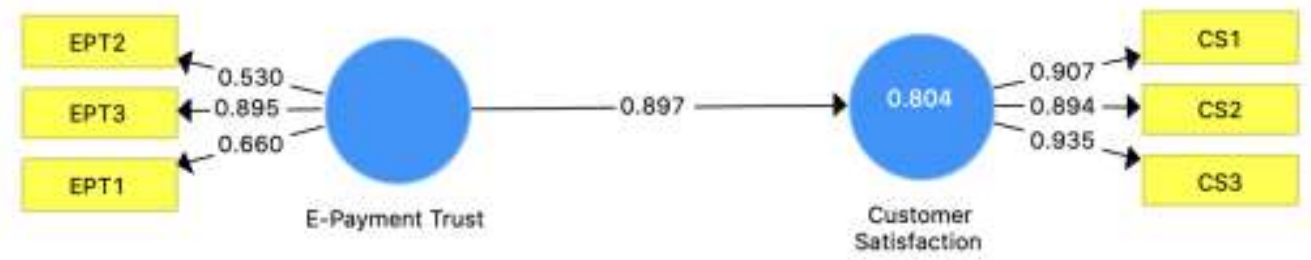

Sumber: Output PLS (2020)

Gambar 2. R-Square

Diketahui bahwa nilai R-Square cukup tinggi yaitu sebesar 0,804 atau 80,4\% artinya variabel eksogen penelitian ini yaitu E-payment trust memiliki kekuatan sebagai predictor terhadap variabel endogen yaitu kepuasan konsumen sebesar $80,4 \%$ hasil ini merupakan angka yang cukup tinggi dalam sebuah penelitian. Path coefficient menunjukkan pengaruh langsung dari eksogen yang ditentukan sebagai penyebab terhadap endogen yang ditentukan sebagai akibat. Jika model rekursif, koefisien jalur dapat dinyatakan dengan menggunakan korelasi sederhana atau regresi berganda. Koefisien jalur sebenarnya adalah koefisien regresi dalam bentuk baku. Besarnya koefisien jalur ini menunjukkan besarnya pengaruh langsung dari peubah eksogen terhadap endogen. Gambar di atas juga memberikan informasi bahwa E-payment trust memiliki path coefficient sebesar 0,897 terhadap kepuasan konsumen.

Dalam statistik, analisis jalur digunakan untuk menggambarkan dependensi terarah di antara serangkaian variabel. Ini termasuk model yang setara dengan segala bentuk analisis regresi berganda, analisis faktor, analisis korelasi kanonik, 
analisis diskriminan, serta keluarga model yang lebih umum dalam analisis multivariat varians dan analisis kovarians (MANOVA, ANOVA, ANCOVA).

Selain dianggap sebagai bentuk regresi berganda yang berfokus pada kausalitas, analisis jalur dapat dipandang sebagai kasus khusus pemodelan persamaan struktural (SEM) - satu di mana hanya indikator tunggal digunakan untuk masing-masing variabel dalam model kausal . Artinya, analisis jalur adalah SEM dengan model struktural, tetapi tidak ada model pengukuran. Istilah lain yang digunakan untuk merujuk pada analisis jalur meliputi pemodelan kausal, analisis struktur kovarian, dan model variabel laten. Analisis jalur dianggap oleh Mutiara Judea sebagai leluhur langsung dengan teknik inferensial Kausal (J. F. Hair et al., 2017).

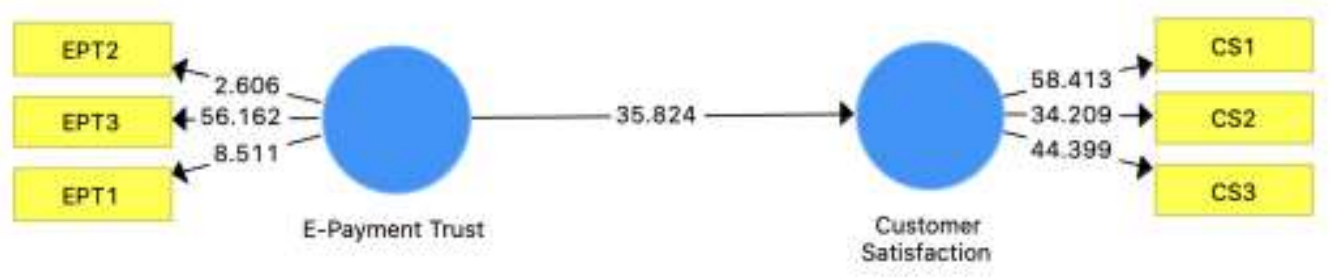

Sumber: Output PLS (2020)

Gambar 3. Path Analysis

Koefisien jalur adalah versi standar dari bobot regresi linier yang dapat digunakan dalam menguji kemungkinan hubungan sebab akibat antara variabel statistik dalam pendekatan pemodelan persamaan struktural. Standardisasi melibatkan mengalikan koefisien regresi biasa dengan standar deviasi dari variabel penjelas yang sesuai: ini kemudian dapat dibandingkan untuk menilai efek relatif dari variabel dalam model regresi pas. Gagasan standardisasi dapat diperluas untuk diterapkan pada koefisien regresi parsial. Istilah "koefisien jalur" berasal dari Wright, di mana pendekatan berbasis diagram tertentu digunakan untuk mempertimbangkan hubungan antara variabel dalam sistem multivariat (J. Hair et $a l ., 2010)$. Ringkasan gambar di atas dapat dilihat pada tabel di bawah ini:

Nilai-T, nilai-P, batas kepercayaan, dan batas keyakinan yang dikoreksi bias juga merupakan output untuk model "kriteria kualitas", seperti R-square, seperti yang ditunjukkan di atas, menunjukkan nilai R-square menjadi signifikan untuk model. Set tabel yang serupa adalah output untuk $\mathrm{R}$ square yang disesuaikan, $\mathrm{f}$ square, average variance extracted (AVE), reliabilitas komposit, alpha Cronbach, rasio heterotraitmonotrait (HTMT), SRMR untuk model faktor umum, dan SRMR untuk model komposit, semua tidak ditampilkan di sini. Semua langkah-langkah ini telah dibahas sebelumnya di bagian algoritma estimasi PLS tradisional untuk menilai kecocokan model karena cukup menggunakan R2 untuk menguji kelayakan model.

Hasil pada Tabel 2. menunjukkan bahwa P-Value 0,000<0,05 sehingga dapat dikatakan $\mathrm{HO}$ ditolak atau Hipotesis alternative dalam penelitian ini diterima artinya terdapat pengaruh yang signifikan antara E-payment trust terhadap kepuasan konsumen. 
Table 2.

Path Coefficient

\begin{tabular}{llll}
\hline \multicolumn{1}{c}{ Path Coefficient } & $\begin{array}{c}\text { Standard } \\
\text { Deviation }\end{array}$ & T-Statistics & P-Value \\
\hline E-Payment Trust $\rightarrow$ Kepuasan Konsumen & 0,025 & 35,824 & 0,000 \\
\hline Sumber: Output PLS (2020) & & &
\end{tabular}

Output Bootstrap juga mencakup histogram yang menunjukkan dispersi nilai estimasi di seluruh iterasi. Misalnya, histogram di bawah ini menunjukkan distribusi koefisien pemuatan jalur untuk jalur model dari SES ke Motivasi. Histogram lain adalah output untuk efek tidak langsung dan efek total. Ini adalah cara grafis untuk menampilkan informasi yang sama seperti yang terkandung dalam interval kepercayaan. Tidak ada histogram untuk model luar (pengukuran).

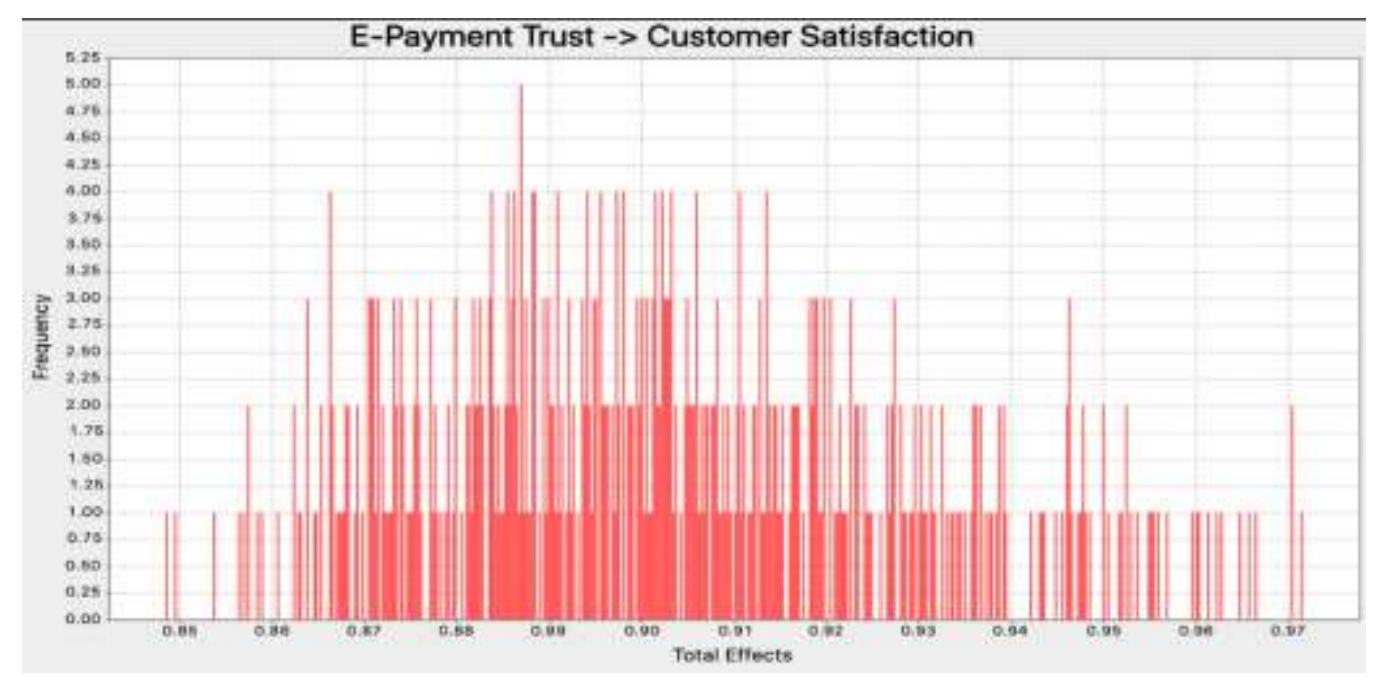

Gambar 4. Total Effects Histogram

Sumber: Output PLS (2020)

Output Bootstrap juga mencakup histogram yang menunjukkan dispersi nilai estimasi di seluruh iterasi. Misalnya, histogram di atas menunjukkan distribusi koefisien pemuatan jalur untuk jalur model mulai dari kepercayaan E-payment hingga kepuasan pelanggan. Ini adalah cara grafis untuk menampilkan informasi yang sama dengan yang terkandung dalam interval kepercayaan. Hasil histogram di atas menunjukkan bahwa efek eksogen terhadap endogen cukup tinggi dapat dilihat dari histogram di atas.

Hasil penelitian ini menunjukkan bahwa E-payment trust merupakan salah satu faktor penting untuk kepuasan konsumen pada E-commerce di Indonesia. Kepercayaan terkait dengan pembayaran sangat berhubungan dengan keamanan informasi dan keamanan data privasi konsumen ketika melakukan transaksi pada E-commerce. Hasil penelitian ini sesuai dengan penelitian sebelumnya yang dilakukan oleh (Putri \& Baridwan, 2014) Dengan adanya sistem E-payment ini memungkinkan untuk memberikan kemudahan dalam bertransaksi daripada memakai uang cash. Selain itu untuk meningkatkan efesiensi pembayaran, 
meningkatkan loyalitas pelanggan dan lebih meningkatkan efektifitas dan efisiensi waktu

Pengaruh kepercayaan dan kepuasan memang berkaitan erat pada penelitian sebelumnya yang memiliki hasil yang sama dengan penelitian ini seperti yang dilakukan oleh (Elbeltagi \& Agag, 2016; Gwebu et al., 2014; Zhu \& Chen, 2012), Ketika pengguna menganggap penyedia layanan pembayaran elektronik dapat diandalkan dan secara umum dapat dipercaya, mereka akan puas dengan pembayaran elektronik dan secara positif mengevaluasi layanan tersebut. Jika pengguna tidak percaya pada pembayaran elektronik, mereka mungkin tidak puas dengan layanan dan menghasilkan evaluasi negatif.

Hasil penelitian ini menjelaskan bahwa faktor pembayaran berupa E-payment pada setiap E-commerce di Indonesia perlu diperhatikan dan dikembangkan baik pada tingkat keamanan atau fasilitas opsi pembayaran cashless yang memudahkan konsumen melakukan transaksi secara online sehingga kepuasan konsumen akan meningkat hal ini akan berkaitan dengan pembelian kembali dan loyalitas dari konsumen terhadap E-commerce sebagaimana yang telah dijelaskan oleh (Kotler \& Keller, 2009) bahwa variabel kepuasan memiliki dampak yang cukup positif terhadap perusahaan.

Setelah mendapatkan hasil penelitian kita mengetahui bahwa E-Payment adalah sistem pembayaran yang menggunakan fasilitas internet sebagai sarana perantara. Saat ini banyak start up yang memfasilitasi pihak penjual dan pembeli dengan memberikan jaminan keamanan transaksi E-commerce. Untuk menjamin keamanan transaksi tersebut, startup yang menjadi perantara akan bekerja sama dengan sejumlah lembaga perbankan untuk mulai memfasilitasi E-payment secara aman, cepat dan praktis. Dengan menggunakan fasilitas E-payment, pihak penjual dan pihak pembeli akan mendapatkan beragam manfaat, antara lain:

Sistem transaksi yang mudah dan dapat dilakukan secara universal selama masih berada dalam 1 wilayah negara. Keamanan transaksi lebih terjaga dibandingkan dengan melakukan transaksi secara cash atau secara transfer rekening pribadi. Penggunaan waktu dan tenaga menjadi lebih simpel dan efisien. Terdapat pihak-pihak yang terlibat dalam fasilitas E-payment, ada beberapa pihak yang terlibat dalam penggunaan dan penyediaan fasilitas E-payment, yakni: Pihak pembeli yang melakukan pembayaran dengan metode e-payment. Pihak penjual yang menerima e-payment. Issuer, berupa lembaga bank atau lembaga non-bank. Pihak pengontrol regulasi (regulator), biasa pihak yang mengawasi dan mengatur proses E-payment adalah pemerintah.

Industri fintech Indonesia saat ini didominasi oleh pemain lokal. Menurut data App Annie Q2 2019, lima aplikasi e-wallet teratas berdasarkan pengguna aktif bulanan dari Google Play Store dan iOS adalah GoPay, OVO, DANA, LinkAja dan Jenius. Pada bulan Februari saja, transaksi yang dilakukan dengan menggunakan GoPay mencapai \$ 6,3 miliar, hampir 70 persen dari total transaksi Gojek. Pertumbuhan OVO yang stabil sebagian besar didukung oleh kemitraannya dengan Grab dan Tokopedia.

Pertama kali diperkenalkan pada tahun 2018, DANA telah berhasil meningkatkan popularitasnya dan menggantikan LinkAja di posisi ketiga di Q2 tahun ini. Diluncurkan pada tanggal 30 Juli, LinkAja telah menikmati posisi yang 
nyaman karena mengintegrasikan layanan pembayaran yang disediakan oleh bankbank milik pemerintah, yaitu TCash Telkomsel, e-cash Bank Mandiri, UnikQu, tMoney Telkom dan T-Bank BRI. Segera akan bermitra dengan Gojek sebagai salah satu opsi pembayaran aplikasi. Berdasarkan jumlah unduhan, lima aplikasi e-wallet teratas adalah GoPay, OVO, DANA, LinkAja, dan iSAKU. Menurut sebuah studi oleh Jakpat Mobile Survey Platform dan DailySocial, 74,6 persen pengguna aplikasi e-wallet di Indonesia berusia 20 hingga 35 tahun (Fahlevi et al., 2019).

Pertumbuhan pesat ini banyak difasilitasi oleh kehadiran marketplace. Dengan kemudahan dalam membuka lapak atau toko online, kini pelaku bisnis dapat menawarkan jasa atau produk secara digital dengan jangkauan konsumen yang lebih luas. Konsumen di era modern cenderung memiliki kebiasaan belanja yang memanfaatkan platform online sekaligus offline. Menurut data dari McKinsey, 20 persen pelanggan Indonesia biasanya melakukan riset produk di toko online sebelum akhirnya membeli produk di toko offline (Suwarni et al., 2020).

Mengutip laporan Corporate Finance Institute (CFI), evaluasi yang akan dilabeli sebagai unicorn tidak ada hubungannya dengan kinerja keuangan masingmasing perusahaan atau data fundamental lainnya. Perlu dicatat bahwa tidak sedikit teknologi dunia perusahaan yang sudah mengantongi status unicorn namun belum menghasilkan keuntungan. Untuk mengantongi status Unicorn adalah proses yang melibatkan berbagai pertimbangan dari banyak faktor. Termasuk memperkirakan pertumbuhan bisnis suatu perusahaan dalam jangka panjang. Selain itu, investor adalah modal dan investor sering menganggapnya sebagai aspek rumit lainnya termasuk pertanyaan keberlanjutan model bisnis. Apalagi jika satu bisnis menjadi perusahaan pertama di industri yang membuat proses penilaian menjadi semakin kompleks.

Berdasarkan penelitian CB Insight, hingga Januari 2019 ada lebih dari 300 unicorn di seluruh dunia. Beberapa unicorn bahkan telah 'naik kelas' dengan mengantongi status sebagai decacorn (nilai US \$ 10 miliar) dan hektocorn (nilai US $\$ 100$ miliar). Lima perusahaan dengan penilaian tertinggi di dunia menurut $C B$ Insight yaitu Toutiao atau Bytedance (US \$ 75 miliar), Uber (US \$ 72 miliar), Didi Chuxing (US \$ 56 miliar), WeWork (US \$ 47 miliar), dan Airbnb (US \$ 29,3 miliar). Sementara di Asia Tenggara sejauh ini ada tujuh unicorn dengan empat termasuk dari Indonesia (Suwarni et al., 2020).

Indonesia saat ini memiliki empat perusahaan Unicorn yang telah mencapai \$ 1 miliar tanpa masuk ke pasar saham. Perusahaan-perusahaan ini meliputi: Gojek, Traveloka, dan pusat-pusat pasar seperti Bukalapak dan Tokopedia (Davies \& Silviana, 2018). Selain itu, berdasarkan pada titik politik-keuangan, Unicorn Indonesia penting karena mereka menjamin perkembangan moneter negara yang lebih penting dan perhatian dunia dalam perekonomian global yang saat ini semakin terdigitasi. Laporan dari Google-Temasek, memperkirakan bahwa kemajuan ekonomi Indonesia dapat naik tiga kali lipat dari \$ 27 miliar pada tahun 2018 menjadi \$ 100 miliar pada tahun 2025 didorong oleh e-commerce, perjalanan naikturun, perjalanan online dan sektor media online, yang semuanya dijamin oleh empat unicorns (Suwarni et al., 2020).

Indonesia kemungkinan besar akan melihat lebih banyak unicorn di tahuntahun berikutnya, dengan sektor-sektor yang paling menjanjikan seperti: 
transportasi, pendidikan, perawatan kesehatan, dan fintech. Namun, dengan lanskap Indonesia yang terus berubah, perusahaan dan investor perlu terus memperbarui diri agar tetap kompetitif dan memanfaatkan peluang pada saat yang tepat. Telah diprediksi bahwa Indonesia akan melahirkan lebih banyak startup berskala tinggi atau bahkan lebih banyak unicorn di masa depan. Ada beberapa nama potensial yang naik ke permukaan, yang berasal dari sektor fintech adalah Modalku dan Kredivo yang dikatakan menjadi unicorn berikutnya. Nama lain yang menjanjikan untuk meraih gelar unicorn adalah dari sektor kesehatan (Arsianews, 2018). Peneliti lain yang mempelajari unicorn sebagian besar mencakup hubungan antara unicorn dan inovasi, efek relatif terhadap ukuran perusahaan dan juga kinerja perusahaan, sementara penelitian ini menekankan pentingnya profitabilitas dalam menjalankan bisnis. Saat ini unicorn di Indonesia termasuk platform e-commerce Tokopedia dan Bukalapak, maskapai dan layanan pemesanan online Traveloka, dan aplikasi naik wahana Go-Jek (Fahlevi et al., 2019).

Potensi industri digital di Indonesia tidak dapat diremehkan. Ada sekitar 93,4 juta pengguna internet dan 71 juta pengguna smartphone di Indonesia saat ini. Kondisi ini merupakan modal besar bagi Indonesia untuk mengembangkan bisnis aplikasi e-commerce dan teknologi digital di Tanah Air. Volume bisnis e-commerce di Indonesia diprediksi mencapai USD 130 miliar dengan tingkat pertumbuhan tahunan sekitar 50 persen. Pemerintah Indonesia berada di bawah koordinasi Kementerian Koordinator Bidang Perekonomian dan bekerja sama dengan Kementerian Komunikasi dan Teknologi Informasi, bekerja untuk membuat peta jalan e-commerce dan ekosistem industri teknologi digital yang terus berkembang dan berkelanjutan.

Presiden Republik Indonesia Joko Widodo telah menyatakan visi untuk menjadikan Indonesia 'Energi Digital Asia' di Lembah Silikon pertengahan Februari tahun ini. Sejalan dengan visi ini, Kementerian Komunikasi dan Informatika bersama dengan KIBAR, memprakarsai Gerakan Nasional 1.000 Startup Digital dengan tujuan melahirkan startup yang berkualitas dan memberikan dampak positif dengan menyelesaikan masalah besar di Indonesia. Gerakan ini ditargetkan untuk menciptakan 1.000 perusahaan baru dengan total penilaian bisnis senilai USD 10 miliar pada tahun 2020. Untuk melahirkan 1.000 startup digital, strategi yang diterapkan adalah melalui pendampingan intensif dan pembinaan melalui tahapan sistematis di 10 kota yang memiliki infrastruktur digital yang kuat dan yayasan. Langkah pertama dimulai dari pengapian - yaitu seminar untuk menanamkan pemikiran kewirausahaan, yang menargetkan 4.000 peserta setiap tahun.

Kemudian, dari peserta penyalaan, 2.000 peserta yang memenuhi syarat akan disaring untuk melanjutkan ke tahap lokakarya untuk diberi keterampilan yang mereka butuhkan untuk membuat startup digital. Berbekal pengetahuan tentang lokakarya, 1.000 peserta akan melanjutkan ke tahap hackathon untuk menghasilkan prototipe produk dari ide solusi aplikasi. Setelah itu, 500 peserta akan memasuki tahap bootcamp, yang merupakan sesi pendampingan mendalam untuk mempersiapkan strategi peluncuran produk. Akhirnya, 200 peserta terpilih akan diinkubasi selama kurang lebih 3 bulan di sekitar kota per tahun, sehingga dalam 5 tahun 1.000 startup digital akan dibuat. Indonesia memiliki keanekaragaman 
budaya yang sangat kaya.

Jika dikombinasikan dengan kekuatan teknologi digital, ini adalah modal besar untuk menghasilkan inovasi dan kreativitas yang begitu unik. Mari kita berhenti bermimpi dan menolak untuk dibuai oleh potensi. Mari kita bergerak bersama dan bekerja untuk menciptakan solusi yang bermanfaat bagi masyarakat Indonesia dan dunia, jelas Kepala Eksekutif KIBAR Yansen Kamto. Gerakan Nasional Digital 1.000 Startup akan diadakan di 10 kota: Jakarta, Bandung, Surabaya, Yogyakarta, Semarang, Malang, Medan, Bali, Makassar, dan Pontianak. Di setiap kota akan dibangun pusat inovasi sebagai titik berkumpul bagi komunitas teknologi, kreatif, dan budaya. Pusat inovasi ini juga menyediakan ruang kerja bersama di mana semua aktor dan pencipta lokal dapat berkolaborasi untuk menciptakan solusi bagi kebutuhan masyarakat lokal untuk berkembang menjadi solusi nasional.

Semua ini adalah manifestasi dari semangat gotong royong di era digital, di mana semua elemen komunitas, mulai dari startup, pembuat, komunitas, akademisi, media, dan pemerintah, bergerak bersama untuk mengembangkan ekosistem dan mendorong terciptanya generasi baru mampu teknologi digital. Mari kita dukung gerakan ini dengan menyebarkan antusiasme, informasi, dan pada saat yang sama terus mendorong perubahan untuk menjadikan Indonesia sebagai 'Energi Digital Asia', kata Rudiantara, Menteri Komunikasi dan Informasi, menyimpulkan peluncuran 1.000 Gerakan Digital Startup Nasional (Suwarni et al., 2020).

Di antara alasan e-commerce mengalami peningkatan yang begitu cepat di Indonesia salah satunya adalah adanya peningkatan yang cepat dari penggunaan smartphone. Smartphone jauh lebih terjangkau dibandingkan komputer dan laptop yang membuatnya mudah diakses oleh sebagian besar orang Indonesia. Ada sekitar $70 \%$ pengguna internet negara ini adalah pengguna smartphone. Laporan McKinsey menyoroti bahwa hampir $75 \%$ pembeli online di Indonesia menggunakan smartphone.

Di sisi lain, pertumbuhan perdagangan informal dapat dikaitkan dengan muda-mudi Indonesia yang mengerti digital. Statistik menunjukkan bahwa anak muda Indonesia adalah pengguna sosial media yang rajin. Negara ini memiliki jumlah pengguna Facebook terbesar keempat di dunia dengan 122 juta orang dan memiliki salah satu populasi terbesar pengguna Instagram. Indonesia juga merupakan negara terbesar kelima dalam hal pengguna Twitter. Dengan begitu banyak pengguna sosial media, tidak mengherankan terjadi perdagangan informal yang besar di negara ini.

\section{SIMPULAN}

Hasil penelitian ini memberikan informasi bahwa E-payment trust merupakan salah satu faktor penting untuk kepuasan konsumen pada E-commerce di Indonesia. Hasil penelitian ini sesuai dengan penelitian sebelumnya yang dilakukan oleh (Putri \& Baridwan, 2014) Sistem pembayaran online membantu dalam meningkatkan kepuasan dan loyalitas pelanggan karena lebih efisien dibandingkan system pembayaran tradisional. Hasil penelitian ini menjelaskan bahwa faktor pembayaran berupa E-payment pada setiap E-commerce di Indonesia perlu diperhatikan dan 
dikembangkan baik pada tingkat kemanan atau fasilitas opsi pembayaran cashless yang memudahkan konsumen melakukan transaksi secara online.

E-commerce di Indonesia mulai berkembang dan menjadi salah satu program pemerintah untuk terus mengembangkan E-commerce, ada sejumlah startup di Indonesia yang telah menjadi status unicorn yang sangat mempengaruhi perekonomian Indonesia saat ini. Startup membantu mendorong pertumbuhan ekonomi dan pertumbuhan di Indonesia, permodalan dan masalah model bisnis adalah masalah utama bagi startup baru di masa-masa awal untuk memulai bisnis mereka. Hal ini diantisipasi oleh pemerintah dengan menciptakan beberapa program untuk mengembangkan startup ke tahap selanjutnya, model bisnis yang digunakan oleh startup di Indonesia juga sangat beragam. Untuk startup yang memiliki status sebagai unicorn, mereka mendapatkan banyak keuntungan, seperti kemudahan menemukan investor untuk berinvestasi di startup mereka dan startup yang telah menjadi unicorn, lebih sering disebut perusahaan, bukan startup dan mereka harus merestrukturisasi perusahaan mereka. Indonesia sebagai negara berkembang merasa perlu untuk melestarikan dan melahirkan startup baru yang bisa go internasional. Penelitian ini membuktikan penelitian sebelumnya yang dilakukan oleh (Suwarni et al., 2020) dan (Fahlevi et al., 2019) bahwa ada beberapa tingkatan dalam startup dan fungsinya terhadap perekonomian suatu negara, startup dapat menjadi pilar ekonomi, terutama di negara-negara berkembang itu membutuhkan pertumbuhan yang baik.

\section{REFERENSI}

Ayo, C. K., \& Ukpere, W. I. (2010). Design of A Secure Unified E-Payment System in Nigeria: A Case Study. African Journal of Business Management, 4(9), 1753-1760.

http://digitalknowledge.cput.ac.za/bitstream/11189/6620/1/Ayo_Charles_K_ Ukpere_Wilfred_Isioma_Bus_2010.pdf

Cao, X., Yu, L., Liu, Z., Gong, M., \& Adeel, L. (2018). Understanding Mobile Payment Users' Continuance Intention: A Trust Transfer Perspective. Internet Research, 28(2), 456-476. https://doi.org/10.1108/IntR-11-20160359

Dwyer, F. R., Schurr, P. H., \& Oh, S. (1987). Developing Buyer-Seller. Journal of Marketing, $51(2)$, $11-27$. https://journals.sagepub.com/doi/abs/10.1177/002224298705100202

Elbeltagi, I., \& Agag, G. (2016). E-Retailing Ethics and Its Impact on Customer Satisfaction and Repurchase Intention: A Cultural and Commitment-Trust Theory Perspective. Internet Research, 26(1), 288-310. https://doi.org/10.1108/IntR-10-2014-0244

Fahlevi, M., Saparudin, M., Maemunah, S., Irma, D., \& Ekhsan, M. (2019). Cybercrime Business Digital in Indonesia. The 4th International Conference 
on Energy, Environment, Epidemiology and Information System (ICENIS 2019), 125, 1-5. https://doi.org/10.1051/e3sconf/201912521001

Gwebu, K. L., Wang, J., \& Guo, L. (2014). Continued Usage Intention of Multifunctional Friend Networking Services: A Test of A Dual-Process Model Using Facebook. Decision Support Systems, 67, 66-77. https://doi.org/10.1016/j.dss.2014.08.004

Hair, J., Black, W., Babin, B., \& Anderson, R. (2010). Multivariate Data Analysis: A Global Perspective. In Multivariate Data Analysis: A Global Perspective.

Hair, J. F., Hult, G. T. M., Ringle, C. M., \& Sarstedt, M. (2017). A Primer on Partial Least Squares Structural Equation Modeling (PLS-SEM) (2nd ed.). Sage.

Hayes, A. F. (2013). Introduction to Mediation, Moderation, and Conditional Process Analysis: A Regression-Based Approach (T. D. Little (ed.)). The Guilford Press.

Horppu, M., Kuivalainen, O., Tarkiainen, A., \& Ellonen, H. K. (2008). Online Satisfaction, Trust and Loyalty, and The Impact of The Offline Parent Brand. Journal of Product and Brand Management, 17(6), 403-413. https://doi.org/10.1108/10610420810904149

Kasbuntoro, Irma, D., Maemunah, S., Mahfud, I., Fahlevi, M., \& Parashakti, R. D. (2020). Work-Life Balance and Job Satisfaction : A Case Study of Employees on Banking Companies in Jakarta. International Journal of Control and Automation, 13(4), 439-451. http://sersc.org/journals/index.php/IJCA/article/view/16461/8242

Kim, C., Tao, W., Shin, N., \& Kim, K. S. (2010). An Empirical Study of Customers' Perceptions of Security and Trust in E-Payment Systems. Electronic Commerce Research and Applications, 9(1), 84-95. https://doi.org/10.1016/j.elerap.2009.04.014

Kotler, P., \& Keller, K. L. (2009). Manajemen Pemasaran. In Jakarta (1st ed.).

Lin, H. H., \& Wang, Y. S. (2006). An Examination of the Determinants of Customer Loyalty in Mobile Commerce Contexts. Information and Management, 43(3), 271-282. https://doi.org/10.1016/j.im.2005.08.001

Linck, K., Pousttchi, K., \& Wiedemann, D. G. (2007). Munich Personal RePEc Archive Security Issues in Mobile Payment from the Customer Viewpoint. 14th European Conference on Information Systems, 2923, 1-11. https://mpra.ub.uni-muenchen.de/2923/1/MPRA_paper_2923.pdf

Mc Knight, D. H., Choudhury, V., \& Kacmar, C. (2002). Developing and Validating Trust Measure for E-Commerce: An Integrative Typology. 
Information Systems Research, 13(3), 334-359. https://doi.org/10.1287/isre.13.3.334.81

Putri, D. W., \& Baridwan, Z. (2014). Determinan Kepercayaan Individu : Studi Empiris Konteks. Jurnal Ilmiah Mahasiswa FEB, 3(1). https://jimfeb.ub.ac.id/index.php/jimfeb/article/view/1553/1422

Saunders, M., Lewis, P., \& Thornhill, A. (2009). Research Methods for Business Students (5th ed.). Prentice Hall.

Sutia, S., Adha, S., \& Fahlevi, M. (2019). Why do Customers Intend to Repurchase Transportation Online in Indonesia? The 4th International Conference on Energy, Environment, Epidemiology and Information System (ICENIS 2019), 125, 1-5. https://doi.org/10.1051/e3sconf/201912523010

Sutia, S., Fahlevi, M., Rita, Rabiah, A. S., \& Adha, S. (2020). The Influence of Endorsement on Instagram toward Customer Behavior. International Journal of Psychosocial Rehabilitation, 24(08), 6628-6634. https://doi.org/10.37200/IJPR/V24I8/PR280685

Suwarni, Noviantoro, R., Fahlevi, M., \& Abdi, M. N. (2020). Startup valuation by venture capitalists: An empirical study Indonesia firms. International Journal of Control and Automation, 13(2), 785-796. http://sersc.org/journals/index.php/IJCA/article/view/11226/5969

Yousafzai, S. Y., Pallister, J. G., \& Foxall, G. R. (2003). A Proposed Model of ETrust for Electronic Banking. Technovation, 23(11), 847-860. https://doi.org/10.1016/S0166-4972(03)00130-5

Zhu, Y. Q., \& Chen, H. G. (2012). Service Fairness and Customer Satisfaction in Internet Banking: Exploring the Mediating Effects of Trust and Customer Value. Internet Research, 22(4), 482-498. https://doi.org/10.1108/10662241211251006 